\title{
Zinc Supplementation and Somatic Cell Count in Milk of Dairy Cows
}

\author{
A. PECHOVÁ, L. PAVLATA, E. LOKAJOVÁ \\ Clinic of Diseases of Ruminants, Faculty of Veterinary Medicine, University of Veterinary \\ and Pharmaceutical Science, Brno, Czech Republic
}

Received July 27, 2005

Accepted May 11, 2006

\begin{abstract}
Pechová A., L. Pavlata, E. Lokajová: Zinc Supplementation and Somatic Cell Count in Milk of Dairy Cows. Acta Vet Brno 2006, 75: 355-361.

The goal of the study was to test the possibility of raising milk zinc ( $\mathrm{Zn}$ ) concentration by increasing the supplementation of $\mathrm{Zn}$, and to assess the effect on the somatic cell count. The experiment was performed at a farm with Czech Pied cattle, with 500 dairy cows and average milk yield 6,390 1. The experiment included 40 dairy cows, assigned to either an experimental $(\mathrm{E}, \mathrm{n}=20)$ or a control group $(\mathrm{C}, \mathrm{n}=20)$ based on the principle of balanced pairs (efficiency, lactation stage). The experimental group was supplemented $\mathrm{Zn}$ in the chelate form (Bioplex $\mathrm{Zn}$, Alltech Inc., Nicholasville, KY), at the dose of $440 \mathrm{mg} \mathrm{Zn} \mathrm{per} \mathrm{animal} \mathrm{per} \mathrm{day.} \mathrm{Blood} \mathrm{and} \mathrm{milk}$ samples were taken at the start of the experiment and at the end of months 1,2 and 3.

The average milk $\mathrm{Zn}$ concentration during the experiment was $57.36 \pm 10.54 \mu \mathrm{mol} \cdot \mathrm{l}^{-1}$, ranging from 38.02 to $86.13 \mu \mathrm{mol} \cdot \mathrm{l}^{-1}$. A trend towards a positive effect of $\mathrm{Zn}$ supplementation on the health of the mammary gland was identified in association with the somatic cell count, which was significantly lower in the experimental group $\left(114.90 \pm 68.7 \cdot 10^{3} \cdot \mathrm{ml}^{-1} \mathrm{vs} .208 .60 \pm 148.1 \cdot 10^{3} \cdot \mathrm{ml}^{-1}\right.$; $p<0.05)$ by the end of month 3 . A negative correlation was found between the somatic cell count and $\mathrm{Zn}$ concentration in milk $(\mathrm{y}=-0.0327 \mathrm{x}+61.557 ; \mathrm{r}=-0.441 ; p<0.01)$. Our results indicate that milk $\mathrm{Zn}$ concentration is not directly affected by the level of zinc supplementation in the feed ration, but zinc supplementation has a positive effect on the somatic cell count.
\end{abstract}

Cattle, blood, milk, microelements, somatic cell count, organic Zn

Zinc ( $\mathrm{Zn})$ is the most abundant intracellular microelement, characterized by a number of catalytic, structural and regulatory functions. Zinc is a biomembrane component playing an essential role in RNA, DNA and ribosome stabilization; it is also present in a number of transcription factors, stabilizes some complexes of hormones and their receptors, plays a role in insulin production and has antioxidant effects. $\mathrm{Zn}$ is also crucial for maintenance of integrity and the barrier function of skin and is involved in the immune system in complex ways. All these functions underlie the positive effect of $\mathrm{Zn}$ on the health status of the mammary gland (Boland et al. 1996), too. Although the specific mechanism of this action has not been known, the assumption is that the increased resistance of the mammary gland is based on the positive effect of $\mathrm{Zn}$ on keratin in the teat duct, its effect on cellular immunity, and the presence of $\mathrm{Zn}$ in a number of acute inflammation proteins (Harmon 1998).

The research of zinc has been devoted much of attention in both human and veterinary medicine. To provide a sufficient status of this microelement in both animals and humans, a range of supplements are used, containing mostly inorganic zinc (oxide, sulphate). Organic zinc, which is more readily utilizable, has recently been used, too. As far as human nutrition is concerned, cow milk, containing 2.3 to $6.6 \mathrm{mg} \cdot \mathrm{l}^{-1}$ of $\mathrm{Zn}$ (Rodriguez et al. 2001), ranks among important sources of zinc. The recommended daily intake of $\mathrm{Zn}$ is $12 \mathrm{mg}$ for women and $15 \mathrm{mg}$ for men (Biesalski and Grimm 1999).

Concentration of $\mathrm{Zn}$ in cow milk has been a rather underrepresented subject in literature

\footnotetext{
Address for correspondence:

Doc. MVDr. Alena Pechová, CSc.

Clinic of Diseases of Ruminants

Faculty of Veterinary Medicine

University of Veterinary and Pharmaceutical Sciences Brno

Palackého 1-3, 61242 Brno

Czech Republic
}

\author{
Phone:+420 541562408 \\ Fax:+420 541562413 \\ E-mail: pechovaa@vfu.cz \\ http://www.vfu.cz/acta-vet/actavet.htm
}


and the factors influencing milk Zn concentration have not been known in detail. In humans, 0.5-1.0 mg of Zn per day is transported through the mammary gland into milk (King 2002) and $\mathrm{Zn}$ transportation into milk is hypothesized to be an active process (Kelleher and Lonnerdal 2003). In cow milk Zn primarily binds to casein and, to a small extent, to citrate. Almost $90 \%$ of $\mathrm{Zn}$ binds to casein in mature milk in contrast to just $60 \%$ in the colostrum (Kincaid and Cronrath 1992). In casein, Zn mainly binds to colloid calcium phosphate in casein micelles ( Silva et al. 2001).

As far as lactation stages are concerned, colostrum and mature milk differ in terms of $\mathrm{Zn}$ content, the concentration of $\mathrm{Zn}$ being higher in colostrum than in mature milk. Pavlata et al. (2004) recorded $\mathrm{Zn}$ concentration in the first milking colostrum $416.76 \pm 120.07 \mu \mathrm{mol} \cdot \mathrm{l}^{-1}$. Peak colostrum Zn concentration 12 hours post-parturition published by V aillancourt and Allen (1991) is $257 \pm 14 \mu \mathrm{mol} \cdot \mathrm{l}^{-1}$, showing a rapid decrease to $141 \pm 8 \mu \mathrm{mol} \cdot \mathrm{l}^{-1} 24$ hours postparturition and to $82 \pm 5 \mu \mathrm{mol} \cdot \mathrm{l}^{-1}$ on post-parturition day 3 . These authors observed a significant increase in milk $\mathrm{Zn}$ concentration after administration of dexamethazone, from which they deduced that the increased $\mathrm{Zn}$ levels in colostrum may be due to an increase in glucocorticoids after parturition, resulting in an increased $\mathrm{Zn}$ transfer from blood into the mammary gland.

The goal of the study was to test the possibility of raising milk $\mathrm{Zn}$ concentration by increasing the supplementation of this microelement in the chelate form in the feed ration. Additionally, the effect of $\mathrm{Zn}$ supplementation on the somatic cell count in milk was studied.

\section{Materials and Methods}

The experiment was performed at a farm keeping Czech Pied cattle, whose total capacity was 500 dairy cows. The average milk yield of the herd was 6,390 1. Stanchion housing with bedding was used and the arrangement of the milk on the rows was by their efficiency. They were fed twice daily. A feeding cart was used to distribute total mixed feed ration ( $1 \mathrm{~kg}$ meadow hay, $5 \mathrm{~kg}$ grass haylage, $5 \mathrm{~kg}$ alfalfa haylage, $21 \mathrm{~kg}$ corn silage, $5 \mathrm{~kg}$ cossettes, $2 \mathrm{~kg}$ grain fodder) computed for the basic milk efficiency of 151 per day. The cows were additionally supplemented a production grain mixture $0.3 \mathrm{~kg}$ per litre of milk. The maximum grain dose was $8 \mathrm{~kg}$ per cow at a production yield of 351 milk. Mineral supplements were administered as part of the basic ration; a small amount was also contained in the production mixture. $\mathrm{Zn}$ supplementation was $1,546 \mathrm{mg}$ in the basic feed ration and $14.3 \mathrm{mg}$ per $1 \mathrm{~kg}$ in production mixture. Cows fed $8 \mathrm{~kg}$ of the mixture thus had 1,660 mg of inorganic $\mathrm{Zn}$ per animal per day.

The experiment included a total of 40 dairy cows in the first half of lactation. They were assigned to either an experimental group $(E, n=20)$ or a control group $(C, n=20)$ based on the principle of balanced pairs (efficiency, lactation stage). The experimental group was supplemented $\mathrm{Zn}$ in the chelate form (Bioplex $\mathrm{Zn}$, Alltech Inc., Nicholasville, KY) at the dose of $2.2 \mathrm{~g}$ per animal per day as part of the grain mixture. The minimum guaranteed $\mathrm{Zn}$ content in Bioplex $\mathrm{Zn}$ was $20 \%$; $\mathrm{Zn}$ supplementation was increased by $440 \mathrm{mg}$ for the milk cows in the experimental group. Blood and milk samples were taken at the start of the experiment and at the end of months 1,2 and 3. The $v$. jugularis was tapped and blood was collected for trace analysis into disposable heparinized plastic tubes. Milk samples were taken from individual milk cows as part of the morning milking and kept free of preservatives; the somatic cell count (SCC) in the samples was determined on the day of collection by a method according to CSN EN ISO 13366-3/1998. Blood plasma and milk Zn concentrations were determined with the help of flame atomic absorption spectrophotometry on an H 1550 device (HILGER, Great Britain). The blood plasma was deproteinized by adding the trichloroacetic acid in the ratio of $1: 1$ for the purposes of the determination proper and $\mathrm{Zn}$ content was determined in the supernatant after centrifugation. The milk was mineralized by the wet process with hydrogen dioxide and nitric acid addition $\left(2 \mathrm{ml} \mathrm{milk}+1 \mathrm{ml} \mathrm{H}_{2} \mathrm{O}_{2}+2 \mathrm{ml}\right.$ $\mathrm{HNO}_{3}$ ) using the microwave digestion technique in the MLS-1200 (Milestone, Italy) microwave oven. The determination was performed in the laboratory of the Clinic of Diseases of Ruminants of the University of Veterinary and Pharmaceutical Sciences Brno.

The findings were evaluated using F-test to assess the variance of the values for the individual populations and, depending on the result, by the Student $t$-test for populations with equal/unequal variances. SCC was compared between the control and experimental group using the non-parametric Wilcoxon's test. The dynamics of the parameters under analysis was assessed with the help of the matched-pair $t$-test. The results are given as the mean value plus the standard deviation. The individual biochemical indicators under analysis were subjected to correlation and regression analysis. The evaluation was performed using Microsoft EXCEL software. 


\section{Results and Discussion}

Milk $\mathrm{Zn}$ concentrations varied from 38.02 to $86.13 \mu \mathrm{mol} \cdot \mathrm{l}^{-1}$ throughout the experiment; the mean concentration was $57.36 \pm 10.54 \mu \mathrm{mol} \cdot \mathrm{l}^{-1}$; the medium concentration $57.43 \mu \mathrm{mol} \cdot \mathrm{l}^{-1}$, and the modal value $61.2 \mu \mathrm{mol} \cdot \mathrm{l}^{-1}$. The milk $\mathrm{Zn}$ concentration found by us in our group of dairy cows was analogical to those quoted by other authors. For a comparison of the milk $\mathrm{Zn}$ concentration found by us with some data from literature see Table 1.

Table 1. Comparison of $\mathrm{Zn}$ concentration in raw cow milk based on literature data

\begin{tabular}{|c|l|}
\hline Zn in milk $\left(\mu \mathrm{mol} \cdot \mathrm{l}^{-1}\right)$ & \multicolumn{1}{|c|}{ Reference } \\
\hline $57.36 \pm 10.54$ & This work \\
\hline $60.56 \pm 2.28$ & Anderson (1992) \\
\hline $67.43 \pm 10.2$ & Rodriguez et al. (2001) \\
\hline $52.29 \pm 0.29$ & Martin-Hernandez et al. (1992) \\
\hline $56.58 \pm 3.36$ & Zurera et al. (1994) \\
\hline $64.37 \pm 6.22$ & Rincon et al. (1994) \\
\hline $64.38 \pm 6.27$ & Moreno et al. (1993a) \\
\hline $57.80 \pm 11.62$ & Lopez-Mahia et al. (1991) \\
\hline
\end{tabular}

Although the milk $\mathrm{Zn}$ concentrations varied considerably throughout the experiment, no statistically significant differences between the groups were observed in none of the samplings (Table 2). The mean $\mathrm{Zn}$ concentration in milk ranged between 40 and $50 \mu \mathrm{mol} \cdot \mathrm{l}^{-1}$ in both the experimental and the control group initially and a significant increase of the $\mathrm{Zn}$

Table 2. Mean concentration of $\mathrm{Zn}$ in blood plasma and milk of cows from experimental $(\mathrm{E} ; \mathrm{n}=20)$ and control groups $(\mathrm{C} ; \mathrm{n}=20)$ during experiment (mean \pm standard deviation)

\begin{tabular}{|l|c|c|c|c|c|}
\hline & Group & Start of the experiment & Month 1 & Month 2 & Month 3 \\
\hline $\begin{array}{l}\text { Zn (plasma) } \\
\left(\mu \mathrm{mol} \cdot \mathrm{l}^{-1}\right)\end{array}$ & $\mathrm{E}$ & $12.28 \pm 1.01$ & $13.08 \pm 1.45$ & $12.70 \pm 1.11$ & $12.75 \pm 1.02$ \\
\cline { 2 - 6 } & $\mathrm{C}$ & $11.69 \pm 1.34$ & $12.16 \pm 1.24$ & $12.19 \pm 1.18$ & $12.27 \pm 0.70$ \\
\hline \multirow{2}{*}{$\begin{array}{l}\mathrm{Zn}(\mathrm{milk}) \\
\left(\mu \mathrm{mol} \cdot \mathrm{l}^{-1}\right)\end{array}$} & $\mathrm{E}$ & $46.05 \pm 3.93$ & $64.43 \pm 7.12^{* * *}$ & $60.74 \pm 8.00^{*}$ & $57.11 \pm 6.69 *$ \\
\cline { 2 - 6 } & $\mathrm{C}$ & $47.50 \pm 4.03$ & $63.67 \pm 9.48^{* * *}$ & $61.66 \pm 7.93$ & $57.73 \pm 5.67$ \\
\hline
\end{tabular}

$* p<0.05$ compared to previous sampling

*** $p<0.001$ compared to previous sampling

level occurred in month 1 of the experimental period. The mean $\mathrm{Zn}$ concentration increased by $18 \mu \mathrm{mol} \cdot \mathrm{l}^{-1}$ in the experimental group and by $16 \mu \mathrm{mol} \cdot \mathrm{l}^{-1}$ in the control group. Milk $\mathrm{Zn}$ concentration showed no significant change from then until the end of the experimental period. It may be somewhat surprising that an analogical rise in milk $\mathrm{Zn}$ concentration occurred in either group after one month of the experimental period despite differing supplementation. We believe that the situation may be due to the incidence of rumen acidosis in the herd before the start of the experiment. The incidence of rumen acidosis was detected by a metabolic test and feed ratios were adjusted prior to the start of the experiment in order to optimize ruminal digestion. The lower milk $\mathrm{Zn}$ concentrations thus may have been a reflection of impaired ruminal fermentation prior to the start of the experiment, and a gradual increase of the milk $\mathrm{Zn}$ concentration occurred in either group after its improvement. Studies focusing on the relation between milk $\mathrm{Zn}$ concentration and the level of supplementation are scarce. Like us, Kirchgessner et al. (1994), who detected only a non-significant increase in milk $\mathrm{Zn}$ content $\left(44.3 \mu \mathrm{mol} \cdot \mathrm{l}^{-1}\right.$ vs. $\left.48.9 \mu \mathrm{mol} \cdot \mathrm{l}^{-1}\right)$ when 
supplementing $2.2 \mathrm{~g} \mathrm{Zn}$ per animal and day in methionin form, did not yield any conclusive proof of an increase in milk Zn concentration either. Stru sinska et al. (2004) detected an increase in colostrum $\mathrm{Zn}$ concentration by 3 - 10\% when supplementing organic microelements. Beňuška et al. (1991) observed an increase in cow milk Zn concentration from 51.5 to $54.4 \mu \mathrm{mol} \cdot \mathrm{l}^{-1}$ on day 8 after intramuscular administration of $\mathrm{Zn}$ at $5 \mathrm{mg} \cdot \mathrm{kg}^{-1}$ live weight. Other factors influencing cow milk $\mathrm{Zn}$ concentration include the breed and the environment. The effect of breed on cow milk Zn concentration was reported by Morales et al. (2000). Holstein cattle showed lower milk Zn concentrations than Jersey cattle $\left(59.6 \mu \mathrm{mol} \cdot \mathrm{l}^{-1}\right.$ vs. $\left.70.3 \mu \mathrm{mol} \cdot \mathrm{l}^{-1}\right)$. An effect of the environment on milk $\mathrm{Zn}$ concentration was observed by Erdogan et al. (2004); higher milk Zn concentrations were reported for a region with no metallurgic industry.

Throughout the experiment, plasma $\mathrm{Zn}$ concentrations did not differ significantly between the experimental and the control group either (Table 2). Analogically, no increase in blood $\mathrm{Zn}$ concentration was found by Boland et al. (1996), who supplemented $300 \mathrm{mg} \mathrm{Zn}$ in bioplex form. A mild increase in $\mathrm{Zn}$ concentration occurred in month 2 , but was not statistically significant. Throughout the experiment, $\mathrm{Zn}$ concentrations were within the lower band of the physiological range $12-18 \mu \mathrm{mol} \cdot \mathrm{l}^{-1}$ in both groups (Vrzgula et al. 1990). A more marked drop in $\mathrm{Zn}$ concentration below $10 \mu \mathrm{mol} \cdot \mathrm{l}^{-1}$ was detected in 2 cows included in the experimental group only (one at the start of the experiment and second at the end of month 2) and in 8 milk cows included in the control group (4 at the start of the experiment, 2 at the end of month 1 and 2 at the end of month 2). It seems likely that these values indicating a deficiency were not due to insufficient zinc supplementation in the feed rations, but due to reduced absorption of the microelement, e.g. as a consequence of rumen dysfunction or due to some individual anomalies, whose cause is difficult to identify. Blood $\mathrm{Zn}$ concentration is modified by other factors such as stress, infection, food intake and hormonal status, too. One of the potential causes may be redistribution of $\mathrm{Zn}$ in the organism in association with some pathological processes. Blood serum zinc decreases by $10-70 \%$ within several hours of the development of the pathological process. Plasma zinc levels decrease to less than $50 \%$ during stress, trauma or inflammatory reactions, and do not reflect the real zinc status of the organism (Zadák 2002).

Table 3. Daily milk production and somatic cell count in milk of cows from experimental $(E ; n=20)$ and control groups $(\mathrm{C} ; \mathrm{n}=20)$ during experiment (mean \pm standard deviation)

\begin{tabular}{|l|c|c|c|c|c|}
\hline & Group & Start of the experiment & Month 1 & Month 2 & Month 3 \\
\hline \multirow{2}{*}{$\begin{array}{l}\text { SCC } \\
\left(10^{3} \cdot \mathrm{ml}^{-1}\right)\end{array}$} & $\mathrm{E}$ & $222.2 \pm 71.9$ & $82.1 \pm 50.7 * * *$ & $33.5 \pm 18.1^{* *}$ & $114.9 \pm 68.7^{\mathrm{a} * *}$ \\
\cline { 2 - 6 } & $\mathrm{C}$ & $273.5 \pm 114.8$ & $80.7 \pm 39.7 * * *$ & $55.2 \pm 43.7$ & $208.6 \pm 148.1^{\text {a } * *}$ \\
\hline $\begin{array}{l}\text { Daily milk } \\
\text { yield(1/day) }\end{array}$ & $\mathrm{E}$ & $22.0 \pm 5.5$ & $23.4 \pm 4.8$ & $22.9 \pm 4.2$ & $22.1 \pm 4.5$ \\
\cline { 2 - 6 } & $\mathrm{C}$ & $19.9 \pm 4.9$ & $21.5 \pm 5.4$ & $21.0 \pm 4.9$ & $20.3 \pm 4.5$ \\
\hline
\end{tabular}

\footnotetext{
${ }^{a} p<0.05$ comparing the experimental and control group (Wilcoxon's test)

$* * p<0.01$ compared to previous sampling

$* * * p<0.001$ compared to previous sampling
}

The somatic cell count in milk cows and the mean milk yield per day in either of the groups are presented in Table 3 . The experimental and the control group differed significantly at the end of month 3 only, when a lower SCC was recorded in the experimental group (114.9 $\pm 68.7 \times 10^{3} \cdot \mathrm{ml}^{-1}$ vs. $\left.208.6 \pm 148.1 \times 10^{3} \cdot \mathrm{ml}^{-1} ; p<0.05\right)$. The somatic cell count however varied considerably throughout the experimental period, with a significant drop of mean values below $100 \times 10^{3} \cdot \mathrm{ml}^{-1}$ in months 1 and 2 . The somatic cell count drop was highly significant in both groups in month 1 and in the experimental group during month 2, too. A significant increase in SCC was then detected in the last sample-taking, with a more 
marked increase in the control group, where the mean SCC increased approximately by $150 \times 10^{3} \cdot \mathrm{ml}^{-1}$ while the increase was only $80 \times 10^{3} \cdot \mathrm{ml}^{-1}$ in the experimental group. The somatic cell count dynamics testifies to a certain positive effect of increased $\mathrm{Zn}$ supplementation, but it seems that it was rather other factors that played the key role.

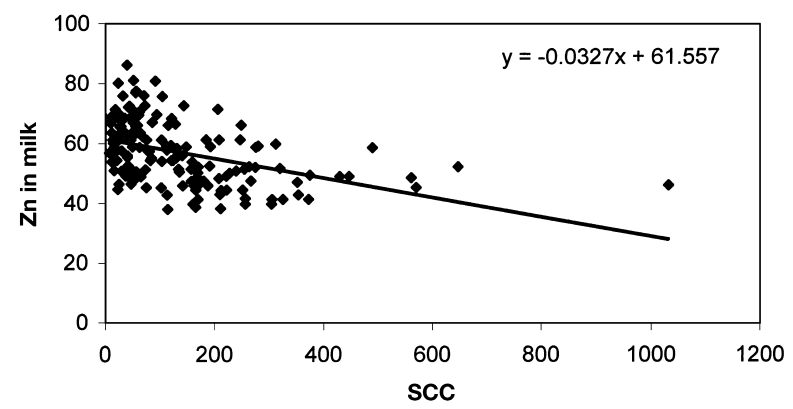

Fig. 1. Relationship between $\mathrm{Zn}$ concentration $\left(\mu \mathrm{mol} \cdot \mathrm{l}^{-1}\right)$ in milk and somatic cell count $\left(10^{3} \cdot \mathrm{ml}^{-1}\right)$ in milk of all examined cows $(n=160)$ with the regression line equation

Milk $\mathrm{Zn}$ concentration and the somatic cell count were found to be negatively correlated $(y=-0.0327 x+61.557 ; \mathrm{r}=-0.441 ; p<0.01)$ (Fig. 1$)$. Studies evidencing the positive effect of zinc supplementation in the feed rations fed to milk cows on the somatic cell count in milk are available in literature. Harris (1995) published the results of a 90-day trial in whose the experimental group of cows was supplemented $\mathrm{Zn}$ in the bioplex form at the dose of $400 \mathrm{mg}$ per animal per day; SCC dropped by $24 \%$ in the supplemented group while it increased by $36 \%$ in the control group over the same period. Also Anders son et al. (2005) investigated the effect of supplementing complexed zinc ( $360 \mathrm{mg} \mathrm{Zn} /$ day per head) from the beginning of the dry period until 3 months post partum. Cows supplemented with zinc produced numerically lower SCC, but the difference between groups was not significant. Boland et al. (1996) published the results of an experiment in which they supplemented $300 \mathrm{mg} \mathrm{Zn}$ in bioplex form, detecting a SCC drop by $45 \%$ but no change in blood $\mathrm{Zn}$ concentration. An increase in $\mathrm{Zn}$ supplementation in the feed rations is not always reflected in an increase in blood $\mathrm{Zn}$ concentration, but using our results, the positive effect of $\mathrm{Zn}$ supplementation on SCC and/or increased utilization of $\mathrm{Zn}$ supplied in the feed ration might be explained by an increased $\mathrm{Zn}$ supply into the mammary gland, where it can have a positive effect on the immune function of cells and reduce the number of somatic cells in milk. This increased supply of $\mathrm{Zn}$ into the mammary gland can then be reflected by an increase in milk $\mathrm{Zn}$ concentration. Only blood $\mathrm{Zn}$ concentration was monitored with respect to the incidence of mastitis. Nare sh et al. (2001) observed significantly lower blood Zn concentration in cows with subclinical mastitis compared to healthy cows. Middleton et al. (2004) found a decrease in blood serum Zn concentration to 83\% in association with Staphylococcus aureus experimental infection.

Our results indicate that milk $\mathrm{Zn}$ concentration is not directly affected by the level of zinc supplementation in the feed ration, but zinc supplementation has a positive effect on the somatic cell count.

\section{Suplementace zinku u dojnic a počet somatických buněk v mléce}

Cílem práce bylo ověření možnosti zvýšení koncentrace zinku $\mathrm{v}$ mléce zvýšenou suplementací tohoto prvku do krmné dávky ve formě chelátu a zhodnocení vlivu zvýšené suplementace zinku na počet somatických buněk v mléce. 
Sledování bylo realizováno v chovu českého strakatého skotu o celkové kapacitě 500 ks dojnic a průměrné dojivosti 6390 1. Do pokusu bylo zařazeno celkem 40 dojnic, které byly na principu analogických dvojic (užitkovost, fáze laktace) rozděleny na skupinu pokusnou $(\mathrm{E}, \mathrm{n}=20)$ a kontrolní $(\mathrm{C}, \mathrm{n}=20)$. Krmná dávka byla u obou skupin dojnic shodná. Pokusné skupině byl přidáván $\mathrm{Zn}$ ve formě chelátu (Bioplex Zn, Alltech Inc. Nicholasville, KY) v dávce $440 \mathrm{mg} Z \mathrm{Zn}$ na kus a den. Na začátku pokusu a dále na konci 1., 2. a 3. měsíce pokusu byly odebírány vzorky krve a mléka. Koncentrace zinku v krevní plazmě a v mléce byla stanovena metodou plamenové atomové absorpční spektrofotometrie.

Suplementace zinku ve formě chelátu do krmné dávky dojnic neovlivnila koncentraci zinku v krevní plazmě ani v mléce. Průměrná koncentrace zinku v mléce v průběhu pokusu byla $57,36 \pm 10,54 \mu \mathrm{mol} \cdot \mathrm{l}^{-1}$ a pohybovala se od 38,02 do $86,13 \mu \mathrm{mol} \cdot \mathrm{l}^{-1}$. Trend pozitivního vlivu suplementace Zn na zdravotní stav mléčné žlázy byl zjištěn v počtu somatických buněk, který byl na konci třetího měsíce signifikantně nižší u pokusné skupiny $(114,90$ $\pm 68,7 \times 10^{3} \cdot \mathrm{ml}^{-1}$ vs. $\left.208,60 \pm 148,1 \times 10^{3} \cdot \mathrm{ml}^{-1} ; p<0,05\right)$. Mezi počtem somatických buněk a koncentrací zinku v mléce byl zjištěn negativní korelační vztah $(\mathrm{y}=-0,0327 \mathrm{x}+61,557$; $\mathrm{r}=-0,441 ; p<0,01)$. Na základě našich výsledků není koncentrace $\mathrm{Zn}$ v mléce přímo ovlivněna výší suplementace tohoto prvku do krmné dávky, ale zvýšený př́ijem má pozitivní vliv na počet somatických buněk.

\section{Acknowledgments}

This work was supported by MSM Project No. 6215712402 "Veterinary Aspects of Foodstuff Safety and Quality".

\section{References}

ANDERSON RR 1992: Comparison of trace elements in milk of 4 species. J Dairy Sci 75: 3050-3055

ANDERSSON R, LEON L, RAPP CH, SOCHA MT, TOMLINSON DJ 2005: The effect of complexed zinc on somatic cell count and lactate dehydrogenace aktivity in dairy cows. In: Mastitis in dairy production (H. Hogeveen ed.), Wageningen Academic Publisher, The Netherlands, $966 \mathrm{p}$.

BEŇUŠKA NM, BÍREŠ J, VRZGULA L 1991: Influence of zinc injectable Zindep inj. a.u.v. (Biotika) on zinc content in milk, muscle and liver of ewes, and in cow milk. Biopharm J Vet Pharm 1: 111-114

BIESALSKI HK, GRIMM P 1999: Taschenatlas der Ernahrung. Georg Thieme Verlag Stuttgart, 314 p.

BOLAND MP, O'DONNELL GO, O'CALLAGHAN D 1996: The contribution of mineral proteinates to production and reproduction in dairy cattle. In: Biotechnology in the Feed Industry, Proceedings of the $12^{\text {th }}$ Annual Symposium (T.P. Lyons and K. A. Jacques, eds.). Nottigham University Press, Loughborough, Leics, UK, pp. 95-102

ERDOGAN S, CELIK S, ERDOGAN Z 2004: Sesonal and locational effects on serum, milk, liver and kidney chromium, manganese, copper, zinc, and iron concentrations of dairy cows. Biol Trace Elem Res 98: 51-61

HARMON RJ 1998: Trace minerals and dairy cattle: importance for udder health. In: Biotechnology in the Feed Industry, Proceedings of the $14^{\text {th }}$ Annual Symposium (T.P.Lyons and K. A. Jacques, eds.). Nottigham University Press, Loughborough, Leics, UK, pp. 485-496

HARRIS B 1995: The effect of feeding zinc proteinate to lactating dairy cows. In: Biotechnology in the Feed Industry, Proceedings of the $11^{\text {th }}$ Annual Symposium (T.P.Lyons and K. A. Jacques, eds.). Nottigham University Press, Loughborough, Leics, UK, pp. 299-306

KELLEHER SL, LONNERDAL B 2003: Zn transporter levels and localization change throughout lactation in rat mammary gland and are regulated by $\mathrm{Zn}$ in mammary cells. J Nutr 133: 3378-3385

KINCAID RL, CRONRATH JD 1992: Zinc concentration and distribution in mammary secretions of prepartum cows. J Dairy Sci 75: 481- 848

KING JC 2002: Enhanced zinc utilization during lactation may reduce maternal and infant zinc depletion. Am J Clin Nutr 75: 2-3

KIRHGESSNER M, PAULICKS BR, HAGEMEISTER H 1994: Zinc concentration in the milk of dairy cows supplemented with high-levels of zinc methionine. J Anim Physiol An N 72: 165-167

LOPEZ-MAHIA, P, PASEIRO-LOSADA, P, SIMAL-LOZANO, J 1991: Elementos traza en leche natural de vaca. Aliment 226: 45-47

MARTIN-HERNANDEZC, AMIGO L, MARTIN-ALVAREZ PJ, JUAREZM 1992: Differentiation of milks and cheeses according to species based on the mineral content. Z Lebensm Unters For 194: 541-544

MIDDLETON JR, LUBY CD, VIERA L, TYLER JW, CASTEEL S 2004: Short communication: Influence of Staphylococcus aureus intramammary infection on serum copper, zinc, and iron concentrations. J Dairy Sci 87: 976-979 
MORALES MS, PALMQUIST DL, WEISS WP 2000: Milk fat composition of Holstein and Jersey cows with control or depleted copper status and fed whole soybeans or tallow. J Dairy Sci 83: 2112- 2119

MORENO R, AMARO M, ZURERA G 1993: Micronutrients an natural cow, ewe and goat milk. Int J Food Sci Nutr 44: 37-46

NARESH R, DWIVEDI SK, DEY S, SWARUP D 2001: Zinc, copper and cobalt concentrations in blood during inflammation of the mammary gland in dairy cows. Asian Austral J Anim Sci 14: 564- 566

PAVLATA L, PECHOVÁ A, DVOŘ́K R 2004: Microelements in Colostrum and Blood of Cows and their Calves during Colostral Nutrition. Acta Vet Brno 73: 421-429

RINCON F, MORENO R, ZURERA G, AMARO M 1994: Mineral composition as a characteristic for the identification of animal origin of milk. J Dairy Res 61: 151-154

RODRIGUEZ EMR, ALAEJOS MS, ROMERO CD 2001: Mineral concentrations in cow's milk from the Canary Island. J Food Comp Anal 14: 419-430

SILVA FV, LOPES GS, NOBREGA JA, SOUZA GB, NOGUEIRA ARA 2001: Study of the protein-bound fraction of calcium, iron, magnesium and zinc in bovine milk. Spectrochim Acta B 56: 1909-1916

STRUSINSKA D, MIEREJEWSKA J, SKOK A 2004: Concentration of mineral components, beta-carotene, vitamins $A$ and $E$ in cow colostrum and milk when using mineral-vitamin supplements. Med Weter 60 : 202-206

VAILLANCOURT SJ, ALLEN JC 1991: Glucocorticoid effects on zinc transport into colostrum and milk of lactating cows. Biol Trace Elem Res 60: 185-196

VRZGULA et al. 1990: Poruch látkového metabolismu hospdárskych zvierat a ich prevencia. Bratislava, Príroda, $2^{\text {nd }}$ edition, $503 \mathrm{p}$.

ZADÁK Z 2002: Výživa v intenzivní péči. Grada Publishing a.s., 496 p.

ZURERA G, MORENO R, AMARO M 1994: Effect of processing on contents and relationships of mineral elements of milk. Food Chem $5 \mathbf{1}$ : 75-78 